\title{
UNDANG-UNDANG HAK CIPTA INDONESIA DAN UNDANG-UNDANG HAK CIPTA MALAYSIA: PERLINDUNGAN DAN PENERAPAN (SEBUAH PERBANDINGAN)
}

\author{
Oleh \\ Rakhmita Desmayanti \\ Fakultas Hukum Universitas Trisakti, Jakarta \\ Email: rakhmitad@yahoo.com
}

\begin{abstract}
Copyright is an exclusive right that grants the creator or the right recipient to perform, display, publish or multiply his creation or to give license for such act to another party without any restrictions based on the existing laws. The term 'creator' refers to an individual or some individuals who jointly share the creating process to produce creations based on their ideas, imagination, dexterity, skills, or expertise expressed in a particularly personal form. The issue of copyright is strongly related to 'the creation', i.e. the creator's work reflecting its originality in science, art, or literature. This research is to provide descriptions on what it takes for a creation to get legal protection under the Law of Copyright in Indonesia and Malaysia and to describe its implementation in both countries. The method used in this research is descriptive in nature, with normative type. The analyzed data are derived from both primary materials-the laws on copyrights in Indonesia and Malaysia-and secondary materials which include related academic books and journals of experts on the matter.
\end{abstract}

Keywords: Copyright in Indonesia, Copyright in Malaysia

\begin{abstract}
Abstrak
Hak cipta adalah yaitu adalah hak eksklusif bagi Pencipta atau penerima Hak untuk mengumumkan atau memperbanyak ciptaannya atau memberikan izin untuk itu dengan tidak mengurangi pembatasan-pembatasan menurut peraturan perundang-undangan yang berlaku. Yang dimaksud dengan Pencipta adalah seorang atau beberapa orang secara bersama-sama yang atas inspirasinya melahirkan suatu ciptaan berdasarkan kemampuan pikiran, imajinasi, kecekatan, ketrampilan, atau keahlian yang dituangkan kedalam bentuk yang khas yang bersifat pribadi. Dalam membicarakan Hak cipta sangat terkait dengan Ciptaan itu sendiri, yaitu adalah hasil setiap karya Pencipta yang menunjukkan keasliannya dalam lapangan ilmu pengetahuan, seni, atau sastra.

Tujuan penelitian ini adalah menggambarkan apa saja yang diperlukan agar suatu karya dapat dilindungi berdasarkan UU Hak Cipta di kedua negara. Juga menggambarkan pelaksanaan perlindungan dan penerapan UU Hak Cipta dikedua negara.

Metode penelitian yang dipergunakan bersifat deskriptif, dengan tipe normatif. Data yang dipergunakan bersumber pada bahan hukum primer yaitu UUHC
\end{abstract}


Indonesia dan Malaysia juga bahan hukum sekunder berupa buku-buku dan tulisan ilmiah para pakar hukum di bidang hukum HKI dll.

Kata Kunci : Hak Cipta di Indonesia, Hak Cipta di Malaysia

\section{PENDAHULUAN}

\section{Latar Belakang}

Hak Kekayaan Intelektual atau disebut juga intelectual property rights adalah hak kebendaan, hak atas sesuatu benda yang bersumber dari hasil kerja otak, hasil kerja rasio. Hasil dari pekerjaan rasio manusia yang menalar. Hasil kerjanya itu berupa benda immateril, benda tidak berwujud. Kita ambil misalnya karya cipta lagu. Untuk menciptakan alunan nada (irama) diperlukan pekerjaan otak. Menurut biologi otak kananlah yang berperan untuk menghayati kesenian, berkhayal, menghayati kerohanian, termasuk juga kemampuan melakkukan sosialisasi danmengendalikan emosi. Fungsi ini disebut sebagai fungsi nonverbal, metaforik, intuitif, holistik dan mampu memproses informasi secara umum. ${ }^{1}$

Hasil kerja otak kemudian dirumuskan sebagai intelektualitas. Orang yang optimal memerankan kerja otaknya disebut sebagai orang yang terpelajar, mampu menggunakan rasio, mampu berpikir secara rasional dengan menggunakan logika (metode berpikir, cabang filsafat), karena itu hasil pemikirannya disebut rasional atau logis. Orang yang tergabung dalam kelompok ini disebut kaum intelektual. Kemampuan otak untuk menulis, berhitung, berbicara, mengingat fakta, dan menghubungkan berbagai fakta menghasilkan ilmu pengetahuan dan teknologi, disebut juga sebagai fungsi preposisi verbal, linguistis, logis dan analitis yang merupakan pekerjaan belahan otak kiri. Uraian ini merupakan asal usul kata intelectual property rights itu. ${ }^{2}$

Tidak semua orang dapat dan mampu mempekerjakan otaknya secara maksimal. Oleh karena itu tak semua orang pula dapat menghasilkan intelectual property rights. Hanya orang yang mampu mempekerjakan otaknya sajalah yang

${ }^{1}$ H. OK. Saidin, Aspek Hukum Kekayaan Intelektual, (Jakarta: Rajagrafindo Persada, 2006), hal. 9-10.

${ }^{2}$ Ibid 
dapat menghasilkan hak kebendaan yang disebut sebagai intelectual property rights. Itu pulalah sebabnya hasil kerja otak yang membuahkan Hak atas Kekayaan Intelektual itu bersifat eksklusif. Hanya orang-orang tertentu saja yang dapat melahirkan hak semacam itu. ${ }^{3}$

Karena untuk menghasilkan suatu buah pikiran manusia tersebut memerlukan keahlian khusus, tenaga dan waktu serta biaya, sudah sepantasnyalah buah pikiran manusia tadi dilindungi secara maksimal. Saat ini sudah ada sistem hukum tersendiri yang mengatur dan melindungi buah pikir manusia yang memiliki nilai tersendiri tadi.

Apa sebenarnya yang dimaksud dengan Hak Kekayaan Intelektual atau yang biasa disingkat dengan HKI atau istilah lain yang sering digunakan adalah Intellectual Property Rights (IPR)? Yakni hak yang timbul bagi hasil olah pikir otak manusia yang menghasilkan suatu produk atau proses yang berguna untuk manusia. Pada intinya HKI adalah hak untuk menikmati secara ekonomis hasil dari suatu kreativitas intelektual. Objek yang diatur dalam HKI adalah karyakarya yang timbul atau lahir dari kemampuan intelektual manusia. ${ }^{4}$

Salah satu instrumen HKI yang dilindungi oleh negara adalah Hak Cipta.

Hak cipta adalah hak yang lahir dengan diwujudkannya suatu ide kedalam suatu bentuk yang termasuk kedalam ruang lingkup perlindungan hak cipta, antara lain : karya musik, seni tari, karya tulis, foto, arsitektur dll. Begitu ide diwujudkan, saat itulah haknya lahir, dan berlakulah perlindungan sesuai dengan UU yang ada.

Berbicara Hak Cipta kita pasti teringat pada beberapa karya cipta negeri ini yang diakui Malaysia sebagai karya cipta mereka, antara lain Reog Ponorogo dan lagu Rasa Sayange.

Hal ini menarik untuk ditelusuri lebih jauh. Apa yang menyebabkan Malaysia berbuat demikian? Adakah perbedaan definisi mengenai suatu karya cipta, ataukah ada perbedaan persyaratan untuk melahirkan suatu ciptaan?

\footnotetext{
${ }^{3}$ Ibid, hal. 11.

${ }^{4}$ Direktorat Jenderal Hak Kekayaan Intelektual, Buku Panduan Hak Kekayaan Intelektual, (Jakarta: Departemen Kehakiman Hak Asasi Manusia Republik Indonesia, 2003), hal. 3.
} 
Karenanya peneliti ingin melakukan penelitian dengan judul UNDANGUNDANG HAK CIPTA INDONESIA DAN UNDANG-UNDANG HAK CIPTA MALAYSIA: PERLINDUNGAN DAN PENERAPAN (SEBUAH PERBANDINGAN).

\section{Perumusan Masalah}

1. Bagaimana sebuah karya dapat dilindungi menurut UU Hak Cipta Indonesia dan Malaysia?

2. Bagaimana pelaksanaan perlindungan dan penerapan berdasarkan UU Hak Cipta Indonesia dan UU Hak Cipta Malaysia?

\section{Metode Penelitian}

\subsection{Sifat Penelitian}

Sifat penelitian ini adalah penelitian hukum bersifat deskriptif, yaitu suatu penelitian yang bertujuan untuk menggambarkan bagaimana perlidungan dan penerapan Undang-undang Hak Cipta di Indonesia dan Malaysia berdasarkan hukum negara masing-masing.

\subsection{Tipe Penelitian}

Tipe penelitian yang dipilih adalah normatif, dimana peneliti berusaha melakukan penelitian terhadap data sekunder berupa Undang-undang Hak Cipta Indonesia yaitu Undang-undang No. 19 Tahun 2002 dan Undangundang Hak Cipta Malaysia yaitu Copyright Act 1987.

\subsection{Sumber Data}

Berdasarkan jenis dan bentuknya, data yang digunakan adalah data sekunder, yang diperoleh melalui studi kepustakaan meliputi :

1. Bahan hukum primer meliputi Undang Undang Hak Cipta Indonesia dan Undang-undang Hak Cipta Malaysia dan peraturan lain yang terkait

2. Bahan hukum sekunder meliputi, buku-buku dan tulisan ilmiah para pakar hukum di bidang hukum HKI dll.

Namun, untuk melengkapi dan mendukung data sekunder diperlukan wawancara. 


\subsection{Cara Pengumpulan Data}

Kegiatan dalam pengumpulan data dalam penelitian ini menggunakan metode Library Research melalui studi kepustakaan dari peraturan perundang-undangan, penelusuran literatur, internet, artikel media massa dan buku ilmiah lainnya. Selain menggunakan metode Library Research, juga dilakukan tehnnik wawancara dengan nara sumber untuk melengkapi pengumpulan data.

\subsection{Analisis Data}

Setelah semua data yang diperlukan terkumpul, data akan diseleksi, dikompilasi, untuk selanjutnya dinalisis secara kualitatif yaitu dengan mengolah data-data yang ada untuk selanjutnya dapat dianalisis guna menjawab pokok permasalahan dalam penelitian ini.

\section{PEMBAHASAN}

\section{Kajian Mengenai Hak Cipta di Indonesia Dan Malaysia}

Apa sebenarnya yang dimaksud dengan Hak Kekayaan Intelektual atau yang biasa disingkat dengan HKI atau istilah lain yang sering digunakan adalah Intellectual Property Rights (IPR)? Yakni hak yang timbul bagi hasil olah pikir otak manusia yang menghasilkan suatu produk atau proses yang berguna untuk manusia. Pada intinya HKI adalah hak untuk menikmati secara ekonomis hasil dari suatu kreativitas intelektual. Objek yang diatur dalam HKI adalah karyakarya yang timbul atau lahir dari kemampuan intelektual manusia. ${ }^{5}$

Maka sudah sewajarnya negara memperhatikan perlindungan terhadap hak kekayaan intelektual yang merupakan hak kekayaan pribadi orang perorang ini.

Perlindungan hukum terhadap hak kekayaan pribadi telah menjadi faktor kunci dalam pertumbuhan kapitalisme dan ekonomi pasar bebas. Sejarah merekam dari masyarakat kuno menunjukkan bahwa orang-orang mengakui "hak" untuk menguasai tanah dan barang, dan dihormati oleh pemerintah untuk

\footnotetext{
${ }^{5}$ Ibid., hal. 3.
} 
melindungi kepentingan mereka dalam kekayaan. Seiring dengan perubahan teknologi konsepsi kekayaan mendapat dampaknya. Sekarang sistem hukum meletakkan kekayaan ke dalam tiga kategori, yakni :

1) Sebagian besar masyarakat mengakui hak kepemilikan pribadi dalam kekayaan pribadi, yang dikenal dengan Intangible things;

2) Kekayaan dalam pengertian riil, seperti tanah dan bangunan;

3) Kekayaan yang diketahui sebagai kekayaan intelektual.

Semua negara mengakui hak kekayaan dalam bentuk produk ide, seperti dalam bentuk hak cipta, paten, merek dan rahasia dagang. ${ }^{6}$

Hak atas Kekayaan Intelektual adalah suatu sistem yang sekarang ini melekat pada tata kehidupan modern. Seperti juga pada aspek-aspek lain yang memberi warna pada kehidupan modern misalnya masalah lingkungan hidup serta persaingan usaha, HKI merupakan konsep yang relatif baru bagi sebagian besar negara, terutama negara-negara berkembang. Namun, pada ujung abad ke-20 dan awal abad ke-21 tercapai kesepakatan negara-negara untuk mengangkat konsep HKI ke arah kesepakatan bersama dalam wujud Agreement Establishing the World Trade Organization ("WTO Agreement") dan segala perjanjian internasional yang lampirannya, termasuk yang menyangkut HKI. ${ }^{7}$

WTO Agreement ini diratifikasi oleh Indonesia dengan Undang-Undang No. 7 tahun 1994 tentang Pengesahan Persetujuan Pembentukan Organisasi Perdagangan Dunia ${ }^{8}$. Dengan demikian secara hukum Indonesia telah terikat dengan ketentuan-ketentuan tentang HaKI dalam GATT (General Agreement on Tariff and Trade atau Persetujuan Umum mengenai Tarif dan Perdagangan). Salah satu lampiran dari persetujuan GATT adalah Persetujuan tentang Aspekaspek Dagang Hak atas Kekayaan Intelektual (Agreement on Trade Related Aspects of Intellectual Property Rights) disingkat TRIPs, yang merupakan standar

6 Budi Agus Riswandi, Hak Kekayaan Intelektual dan Budaya Hukum, (Jakarta: RajaGrafindo Persada, 2005), hal. 30-31.

${ }^{7}$ Achmad Zen Umar Purba, Hak Kekayaan Intelektual Pasca TRIPs, (Bandung: Alumni, 2005), hal. 1.

${ }^{8}$ Diundangkan tanggal 2 November 1994 dan dimuat dalam Lembaran Negara Nomor 57 dan Tambahan Lembar Negara Nomor 3564. 
internasional yang harus disepakati berkaitan dengan HKI. HKI terdiri dari Hak Cipta dan hak-hak yang terkait, Merek Dagang, Indikasi Geografis, Desain Industri, Paten, Hak atas Topografi Rangkaian Terpadu Semikonduktor, Perlindungan mengenai Undisclosed Information, dan Pengawasan Terhadap Praktek yang Membatasi Konkurensi Dalam Kontrak Lisensi. ${ }^{9}$

Sebenarnya bagi Indonesia, pelaksanaan hak kekayaan intelektual bukan hanya karena TRIPs. Sejarah menunjukkan Indonesia mengenal dan menerapkan TRIPs sejak lama, bahkan sejak zaman Hindia Belanda. Hal ini mudah pula dipahami mengingat Belanda, seperti juga dengan negara-negara lain yang pernah melakukan kolonisasi, berkepentingan untuk menyebarkan paham tentang perlindungan atas karya intelektual ini untuk kesuksesan pihaknya sendiri. ${ }^{10}$

TRIPs adalah suatu perjanjian internasional. Kelahirannya telah sempurna dan didukung oleh mayoritas negara di dunia ini. Walaupun demikian hingga sekarang TRIPs masih terus dalam sorotan termasuk oleh negara-negara berkembang berkenaan dengan bebeerapa isu tertentu. Sebagai bagian dari WTO Agremeens, TRIPs merupakan perjanjian internasional yang punya peranan penting. Artinya, suatu negara tidak dapat menerapkan sistem hak kekayaan intelektual tanpa ada referensi kepentingan khusus bagi perekonomiannya atau secara umum pembangunan negara tersebut. Sementara itu, tidak dapat dilupakan bahwa TRIPs sebagai instrumen hukum dalam hukum internasional tidak luput dari pertentangan antara negara anggotanya, teramat khusus antara negara-negara maju di satu pihak dan negara-negara berkembang di lain pihak. Inipun tidak mengherankan lantaran polarisasi negara-negara maju dan negara-negara berkembang merupakan warna dunia setelah Perang Dunia II yakni dengan telah merdekanya sejumlah negara di Asia dan Afrika. ${ }^{11}$

Selain TRIPs, ada Konvensi Internasional yang khusus melindungi karya sastra dan karya seni. Konvensi ini dikenal dengan Konvensi Bern, yang

9 Cita Citrawinda Priapantja, Budaya Hukum Indonesia Menghadapi Globalisasi Perlindungan Rahasia Dagang di bidang Farmasi, Jakarta: Chandra Pratama, 1999), hal. 2.

${ }^{10}$ Achmad Zen Purba, Op. Cit., hal. 7.

${ }^{11}$ Ibid., hal. 8. 
memberikan ruang lingkup hak cipta sebagai karya sastra dan seni. Ada juga Universal Copyright Convention (UCC), memberikan ruang lingkup meliputi karya sastra, ilmu pengetahuan, dan seni. Tetapi pada prinsipnya kedua cakupan hak cipta tersebut sama, bahkan Konvensi Bern lebih terperinci. ${ }^{12}$

Undang-undang Hak Cipta (UUHC) di Indonesia saat ini adalah Undangundang No. 19 Tahun 2002 tentang Hak Cipta. Definisi Hak Cipta dapat kita lihat dalam Pasal 1 angka 1 UU ini, yaitu adalah hak eksklusif_ bagi Pencipta atau penerima Hak untuk mengumumkan atau memperbanyak ciptaannya atau memberikan izin untuk itu dengan tidak mengurangi pembatasan-pembatasan menurut peraturan perundang-undangan yang berlaku. Yang dimaksud dengan Pencipta adalah seorang atau beberapa orang secara bersama-sama yang atas inspirasinya melahirkan suatu ciptaan berdasarkan kemampuan pikiran, imajinasi, kecekatan, keterampilan, atau keahlian yang dituangkan kedalam bentuk yang khas yang bersifat pribadi. Dalam membicarakan Hak cipta sangat terkait dengan Ciptaan itu sendiri, yaitu adalah hasil setiap karya Pencipta yang menunjukkan keasliannya dalam lapangan ilmu pengetahuan, seni, atau sastra.

Syarat suatu hasil karya cipta dapat dilindungi berdasarkan UUHC adalah karya tersebut adalah asli hasil karya dari pencipta, karya tersebut ada dalam lapangan ilmu pengetahuan, seni dan sastra. Juga merupakan suatu karya yang baru, tidak menyerupai atau sama dengan karya-karya yang sudah pernah ada.

Hak cipta lahir secara otomatis setelah ide yang ada dituangkan kedalam suatu bentuk. Bentuk-bentuk yang dilindungi dengan UUHC adalah :

a. buku, program komputer, pamflet, perwajahan (lay out) karya tulis yang diterbitkan, dan semua hasil karya tulis lain;

b. ceramah, kuliah, pidato, dan ciptaan lain yang sejenis dengan itu;

c. alat peraga yang dibuat untuk kepentingan pendidikan dan ilmu pengetahuan;

d. lagu atau musik dengan atau tanpa teks;

e. drama atau drama musikal, tari, koreografi, pewayangan, dan pantomim;

${ }^{12}$ Taryana Soenandar, Perlindungan Hak Milik Intelektual di Negara-Negara ASEAN, Jakarta: Sinar Grafika, 1996), hal. 
f. seni rupa dalam segala bentuk seperti seni lukis, gambar, seni ukir, seni kaligrafi, seni pahat, seni patung, kolase dan seni terapan;

g. arsitektur;

h. peta;

i. seni batik;

j. fotografi;

k. sinematografi;

1. terjemahan, tafsir, saduran, bunga rampai, data base, dan karya lain dasi hasil pengalihwujudan. (Pasal 12 ayat 1 UUHC)

Dalam Hak Cipta pendaftaran bukanlah merupakan hal yang wajib dilakukan dan melahirkan Hak. Pendaftaran Hak Cipta berfungsi sebagai bukti adanya suatu karya yang didaftarkan.

Jangka waktu perlindungan Hak Cipta atas ciptaan :

a. buku, pamflet, dan semua hasil karya tulis lain;

b. drama atau drama musikal, tari, koreografi;

c. segala bentuk seni rupa, seperti seni lukis, seni pahat, dan seni patung;

d. seni batik;

e. lagu atau musik dengan atau tanpa teks;

f. arsitektur;

g. ceramah, kuliah, pidato dan ciptaan sejenis lain;

h. alat peraga;

i. peta;

j. terjemahan, tafsir, saduran, dan bunga rampai;

berlaku selama hidup pencipta dan terus berlangsung hingga 50 (lima puluh) tahun setelah pencipta meninggal dunia.

Untuk ciptaan yang dimiliki oleh 2 orang atau lebih, maka perlindungan berlaku selama hidup pencipta yang meninggal dunia paling akhir dan berlangsung hingga 50 (lima puluh) tahun sesudahnya. (Pasal 29 UUHC)

Sedangkan untuk ciptaan berupa :

a. Program komputer; 
b. Sinematografi;

c. Fotografi;

d. Database;

e. Karya hasil pengalihwujudan;

berlaku selama 50 (lima puluh) tahun sejak pertama kali diumumkan.

Demikian juga untuk ciptaan berupa perwajahan karya tulis dan juga bila pemegang hak cipta adalah suatu badan hukum . (Pasal 30 UUHC)

Pendaftaran Hak Cipta dilakukan di Direktorat Jenderal Hak Kekayaan Intelektual yang berada di bawah Kementerian Hukum dan HAM.

Di Malaysia Hak Cipta dilindungi dengan Copyright Act 1987. Dalam undang-undang ini menyebutkan, Hak Cipta adalah hak eksklusif yang diberikan kepada pemilik hak cipta dalam jangka waktu tertentu. Perlindungan diperoleh secara otomatis tanpa diperlukan pendaftaran terlebih dahulu, asalkan hasil karya cipta memenuhi syarat-syarat sebagai berikut:

- Karya tersebut asli hasil karya dari pemilik Hak

- Karya sudah diwujudkan dalam suatu bentuk yang termasuk ruang lingkup Hak Cipta

- Karya tersebut pertama kali dipublikasikan di Malaysia.

Ciptaan yang dilindungi di Malaysia meliputi :

- Karya sastra

- Karya Musik

- Karya Seni

- Film

- Rekaman suara

- Broadcast

- Karya berupa pengalihwujudan

Karya yang dapat perlindungan adalah karya yang sudah diwujudkan dalam suatu bentuk yang merupakan ruang lingkup Hak Cipta, jadi bukan merupakan ide.

Pemilik Hak Cipta di Malaysia adalah mereka yang menghasilkan karya tersebut. Jika suatu karya dihasilkan seorang pegawai sebagai suatu tugas dan 
tanggung jawab dalam pekerjaannya, maka pemilik Hak Cipta adalah pemberi pekerjaan.

Jangka waktu perlindungan Hak cipta untuk karya tulis, karya musik, dan karya seni dilindungi seumur hidup pencipta dan dapat diperpanjang selama 50 tahun sejak meninggalnya pencipta. Jika pencipta ada 2 orang jangka waktu seumur hidup pencipta yang hidup terlama dan perpanjangan 50 tahun sejaka pencipta terakhir meninggal dunia.

Untuk karya cipta berupa rekaman suara, jangka waktunya 50 tahun sejak pertama kali dipublikasikan. Juga untuk karya berupa hak penyiaran dan film.

\section{ANALISIS HASIL PENELITIAN DAN PEMBAHASAN}

\subsection{Perlindungan Hak Cipta di Indonesia berdasarkan Undang-undang Hak Cipta No. 19 tahun 2002 (UUHC)}

Konsep hak cipta di Indonesia merupakan terjemahan dari konsep copyright dalam bahasa Inggris (secara harafiah artinya "hak salin"). Copyright ini diciptakan sejalan dengan penemuan mesin cetak. Sebelum penemuan mesin ini oleh Gutenberg, proses untuk membuat salinan dari sebuah karya tulisan memerlukan tenaga dan biaya yang hampir sama dengan proses pembuatan karya aslinya. Sehingga, kemungkinan besar para penerbitlah, bukan para pengarang, yang pertama kali meminta perlindungan hukum terhadap karya cetak yang dapat disalin. $^{13}$

Awalnya, hak monopoli tersebut diberikan langsung kepada penerbit untuk menjual karya cetak. Baru ketika peraturan hukum tentang copyright mulai diundangkan pada tahun 1710 dengan Statute of Anne di Inggris, hak tersebut diberikan ke pengarang, bukan penerbit. Peraturan tersebut juga mencakup perlindungan kepada konsumen yang menjamin bahwa penerbit tidak dapat mengatur penggunaan karya cetak tersebut setelah transaksi jual beli berlangsung. Selain itu, peraturan tersebut juga mengatur masa berlaku hak eksklusif bagi

13 Dodi Ft, "Sekilas tentang Hak Cipta", [www.kompasiana.com], diakses tanggal 19 Februari 2010 
pemegang copyright, yaitu selama 28 tahun, yang kemudian setelah itu karya tersebut menjadi milik umum. ${ }^{14}$

Berne Convention for the Protection of Artistic and Literary Works ("Konvensi Bern tentang Perlindungan Karya Seni dan Sastra" atau "Konvensi Bern”) pada tahun 1886 adalah yang pertama kali mengatur masalah copyright antara negara-negara berdaulat. Dalam konvensi ini, copyright diberikan secara otomatis kepada karya cipta, dan pengarang tidak harus mendaftarkan karyanya untuk mendapatkan copyright. Segera setelah sebuah karya dicetak atau disimpan dalam satu media, si pengarang otomatis mendapatkan hak eksklusif copyright terhadap karya tersebut dan juga terhadap karya derivatifnya, hingga si pengarang secara eksplisit menyatakan sebaliknya atau hingga masa berlaku copyright tersebut selesai. $^{15}$

Hak cipta di Indonesia dilindungi berdasarkan UUHC No. 12 tahun 2002. UUHC merupakan rangkaian dari Undang-undang Hak Kekayaan Intelektual (HKI) yang harus dimiliki setelah Indonesia meratifikasi World Trade Organization (WTO) Agreement dengan Undang-undang No.7 tahun 1994. Dengan demikian secara hukum Indonesia telah terikat dengan ketentuanketentuan tentang HKI dalam GATT (General Agreement on Tariff and Trade atau Persetujuan Umum mengenai Tarif dan Perdagangan). Salah satu lampiran dari persetujuan GATT adalah Persetujuan tentang Aspek-aspek Dagang Hak atas Kekayaan Intelektual (Agreement on Trade Related Aspects of Intellectual Property Rights) disingkat TRIPs, yang merupakan standar internasional yang harus disepakati berkaitan dengan HKI.

Sejak lama di Indonesia telah diatur peraturan hukum tentang hak cipta berdasarkan Auteurswet 1912, Staatsblad 1912 No. 600, yang berdasarkan Aturan Peralihan Pasal II UUD 1945, diberlakukan setelah Indonesia merdeka. ${ }^{16}$

Indonesia baru berhasil membuat undang-undang hak cipta sendiri pada tahun 1982 dengan dikeluarkannya Undang-undang No. 6 tahun 1982 tentang Hak

\footnotetext{
${ }^{14}$ Ibid.

${ }^{15}$ Ibid.

${ }^{16}$ Ibid., hal. 9 .
} 
Cipta. Undang-undang ini sekaligus mencabut Auteurswet 1912, juga dimaksudkan untuk mendorong dan melindungi penciptaan, menyebarluaskan hasil kebudayaan di bidang karya ilmu, seni, dan sastra, serta mempercepat pertumbuhan pencerdasan bangsa. ${ }^{17}$

Selanjutnya pada tahun 1987, Undang-undang Hak Cipta 1982 disempurnakan dengan Undang-undang No. 7 tahun 1987 tentang perubahan atas Undang-undang Hak Cipta No. 6 tahun 1982 tentang Hak Cipta. Penyempurnaan ini dimaksudkan menumbuhkan iklim yang lebih baik bagi tumbuh dan berkembangnya gairah mencipta di bidang ilmu pengetahuan, seni dan sastra. Penyempurnaan berikutnya adalah pada tahun 1997 dengan berlakunya Undangundang No. 12 tahun 1997. Penyempurnaan ini diperlukan sehubungan perkembangan kehidupan yang berlangsung cepat, terutama dibidang perekonomian tingkat nasional dan internasional yang menuntut pemberian perlindungan yang lebih efektif terhadap hak cipta. Selain itu juga karena penerimaan dan keikutsertaan Indonesia di dalam Persetujuan TRIP's yang merupakan bagian dari Agreement Establishing the World Trade Organization. ${ }^{18}$

Akhirnya pada tahum 2002, UUHC yang baru diundangkan dan menggantikan Undang-undang No. 12 tahun 1997 dengan UUHC No. 19 tahun 2002. UUHC ini memuat perubahan-perubahan yang disesuaikan dengan TRIP's dan penyempurnaan beberapa hal yang perlu untuk memberikan perlindungan bagi karya-karya intelektual di bidang hak cipta, termasuk upaya untuk memajukan perkembangan karya intelektual yang berasal dari keanekaragaman seni dan budaya tradisional Indonesia. ${ }^{19}$

Perubahan undang-undang tersebut juga tak lepas dari peran Indonesia dalam pergaulan antar negara. Pada tahun 1994, pemerintah meratifikasi pembentukan Organisasi Perdagangan Dunia (World Trade Organization - WTO), yang mencakup pula Agreement on Trade Related Aspects of Intellectual hal. 17 .

${ }^{17}$ Afriliyani Purba, TRIP's-WTO \& Hukum HKI Indonesia, (Bandung: Rineka Cipta, 2005),

\footnotetext{
${ }^{18}$ Ibid., hal. 18.

${ }^{19}$ Ibid.
} 
Propertyrights - TRIPs ("Persetujuan tentang Aspek-aspek Dagang Hak Kekayaan Intelektual"). Ratifikasi tersebut diwujudkan dalam bentuk Undangundang Nomor 7 Tahun 1994. Pada tahun 1997, pemerintah meratifikasi kembali Konvensi Bern melalui Keputusan Presiden Nomor 18 Tahun 1997 dan juga meratifikasi World Intellectual Property Organization Copyrights Treaty ('Perjanjian Hak Cipta WIPO") melalui Keputusan Presiden Nomor 19 Tahun $1997 . .^{20}$

Definisi Hak Cipta dapat kita lihat dalam Pasal 1 angka 1 UU ini, yaitu adalah hak eksklusif bagi Pencipta atau penerima Hak untuk mengumumkan atau memperbanyak ciptaannya atau memberikan izin untuk itu dengan tidak mengurangi pembatasan-pembatasan menurut peraturan perundang-undangan yang berlaku. Yang dimaksud dengan Pencipta adalah seorang atau beberapa orang secara bersama-sama yang atas inspirasinya melahirkan suatu ciptaan berdasarkan kemampuan pikiran, imajinasi, kecekatan, ketrampilan, atau keahlian yang dituangkan kedalam bentuk yang khas yang bersifat pribadi. Dalam membicarakan Hak cipta sangat terkait dengan Ciptaan itu sendiri, yaitu adalah hasil setiap karya Pencipta yang menunjukkan keasliannya dalam lapangan ilmu pengetahuan, seni, atau sastra.

Syarat suatu hasil karya cipta dapat dilindungi berdasarkan UUHC adalah karya tersebut adalah asli hasil karya dari pencipta, karya tersebut ada dalam lapangan ilmu pengetahuan, seni dan sastra. Juga merupakan suatu karya yang baru, tidak menyerupai atau sama dengan karya-karya yang sudah pernah ada.

Hak cipta lahir secara otomatis setelah ide yang ada dituangkan kedalam suatu bentuk. Bentuk-bentuk yang dilindungi dengan UUHC adalah :

a. buku, program komputer, pamflet, perwajahan (lay out) karya tulis yang diterbitkan, dan semua hasil karya tulis lain;

b. ceramah, kuliah, pidato, dan ciptaan lain yang sejenis dengan itu;

c. alat peraga yang dibuat untuk kepentingan pendidikan dan ilmu pengetahuan;

d. lagu atau musik dengan atau tanpa teks;

\footnotetext{
${ }^{20}$ Dodi Ft, Loc. Cit.
} 
e. drama atau drama musikal, tari, koreografi, pewayangan, dan pantomim;

f. seni rupa dalam segala bentuk seperti seni lukis, gambar, seni ukir, seni kaligrafi, seni pahat, seni patung, kolase dan seni terapan;

g. arsitektur;

h. peta;

i. seni batik;

j. fotografi;

k. sinematografi;

1. terjemahan, tafsir, saduran, bunga rampai, data base, dan karya lain dasi hasil pengalihwujudan. (Pasal 12 ayat 1 UUHC)

Dalam Hak Cipta pendaftaran bukanlah merupakan hal yang wajib dilakukan dan melahirkan Hak. Pendaftaran Hak Cipta berfungsi sebagai bukti adanya suatu karya yang didaftarkan.

Jangka waktu perlindungan Hak Cipta atas ciptaan :

a. buku, pamflet, dan semua hasil karya tulis lain;

b. drama atau drama musikal, tari, koreografi;

c. segala bentuk seni rupa, seperti seni lukis, seni pahat, dan seni patung;

d. seni batik;

e. lagu atau musik dengan atau tanpa teks;

f. arsitektur;

g. ceramah, kuliah, pidato dan ciptaan sejenis lain;

h. alat peraga;

i. peta;

k. terjemahan, tafsir, saduran, dan bunga rampai;

berlaku selama hidup pencipta dan terus berlangsung hingga 50 (lima puluh) tahun setelah pencipta meninggal dunia.

Untuk ciptaan yang dimiliki oleh 2 orang atau lebih, maka perlindungan berlaku selama hidup pencipta yang meninggal dunia paling akhir dan berlangsung hingga 50 (lima puluh) tahun sesudahnya. (Pasal 29 UUHC)

Sedangkan untuk ciptaan berupa :

a. Program komputer; 
b. Sinematografi;

c. Fotografi;

d. Database;

e. Karya hasil pengalihwujudan;

Demikian juga untuk ciptaan berupa perwajahan karya tulis dan juga bila pemegang hak cipta adalah suatu badan hukum . (Pasal 30 UUHC)

UUHC juga melindungi karya-karya yang masuk kedalam kategori budaya bangsa atau dikenal dengan istilah folklore dalam pasal 10. Pemegang hak cipta untuk karya-karya tersebut adalah negara. Jika ada orang yang bukan warga negara Indonesia ingin mengumumkan atau memperbanyak karya-karya tersebut, harus mendapat izin dari negara.

Dalam rangka melindungi folklor dan hasil kebudayaan rakyat lain, Pemerintah dapat mencegah adanya monopoli atau komersialisasi serta tindakan yang merusak atau pemanfaatan komersial tanpa seizin negara Republik Indonesia sebagai Pemegang Hak Cipta. Ketentuan ini dimaksudkan untuk menghindari tindakan pihak asing yang dapat merusak nilai kebudayaan tersebut. Folklor dimaksudkan sebagai sekumpulan ciptaan tradisional, baik yang dibuat oleh kelompok maupun perorangan dalam masyarakat, yang menunjukkan identitas sosial dan budayanya berdasarkan standar dan nilai-nilai yang diucapkan atau diikuti secara turun temurun, termasuk:

a. cerita rakyat, puisi rakyat;

b. lagu-lagu rakyat dan musik instrumen tradisional;

c. tari-tarian rakyat, permainan tradisional;

d. hasil seni antara lain berupa: lukisan, gambar, ukiran-ukiran, pahatan, mosaik, perhiasan, kerajinan tangan, pakaian, instrumen musik dan tenun tradisional.

Hal ini termuat dalam penjelasan Pasal 10 (2) UUHC.

Dewasa ini perkembangan karya-karya cipta sangatlah pesat. Hal ini kurang sebanding dengan pemahaman masyarakat umum terhadap hak cipta secara khusus. Kondisi seperti ini yang menyebabkan maraknya pelanggaran terhadap karya cipta. 
Pemerintah menaruh perhatian yang cukup besar untuk menanggulangi pelanggaran HKI, yaitu dengan dibentuknya Tim Nasional Penanggulangan Pelanggaran HKI, berdasarkan Keppres No. 4 tahun 2006 dan dibentuknya Direktorat Penyidikan di Direktorat Jenderal HKI oleh Kementrian Hukum dan HAM pada tahun 2010.

UUHC juga mensyaratkan terbentuknya badan yang be.rtugas melakukan pembimbingan dan pembinaan. Dewan ini dikenal dengan nama Dewan Hak Cipta. Selain Dewan Hak Cipta juga terdapat sejumlah asosiasi hak cipta, yaitu :

- KCI : Karya Cipta Indonesia

- ASIRI : Asosiasi Industri Rekaman Indonesia

- ASPILUKI : Asosiasi Piranti Lunak Indonesia

- APMINDO : Asosiasi Pengusaha Musik Indonesia

- ASIREFI : Asosiasi Rekaman Film Indonesia

- PAPPRI : Persatuan Artis Penata Musik Rekaman Indonesia

- IKAPI : Ikatan Penerbit Indonesia

- MPA : Motion Picture Assosiation

- BSA : Bussiness Software Assosiation

Disamping adanya Dewan Hak Cipta dan Asosiasi Hak Cipta, yang mengapresiasi perlindungan hak cipata, Majelis Ulama indonesia (MUI) juga mengeluarkan keputusan untuk melindungi hak cipta. Melalui keputusan fatwa Komisi Fatwa MUI No. 1 tahun 2003 tentang Hak Cipta yang menyatakan bahwa Setiap bentuk pelanggaran terhadap Hak Cipta, terutama pembajakan, merupakan kezaliman yang hukumnya adalah HARAM.

\subsection{Perlindungan Hak Cipta di Malaysia berdasarkan Undang-Undang Hak Cipta Malaysia, Copyright Act 1987 (Act 332) \\ Perlindungan Hak Cipta di Malaysia sudah dimulai sejak zaman Inggris} berkuasa di Malaysia. Undang-undang yang berlaku saat itu adalah Act 1911. Setelah Malaysia merdeka undang-undang Hak Cipta yang berlaku adalah Copyright Act 1969 yang berlaku hingga tahun 1987. Sejak saat itu undangundang yang dipergunakan adalah Act 332. 
Di Malaysia Hak Cipta dilindungi dengan Copyright Act 1987 yaitu Act 332. Act 332 telah mengalami beberapa kali perubahan. Diantaranya amandemen tahun 1997 Act A994, amandemen tahun 2000 Act A 1082, amandemen tahun 2002 Act A 1131. Amandemen-amandemen terhadap Act 332 hanya perubahan kecil. Undang-undang yang dipakai secara utuh adalah Act 332.

Malaysia meratifikasi Berne Convention tahun 1990 dan menjadi anggota WTO tahun 1996.

Dalam Act 332 menyebutkan, Hak Cipta adalah hak eksklusif yang diberikan kepada pemilik hak cipta dalam jangka waktu tertentu. Perlindungan diperoleh secara otomatis tanpa diperlukan pendaftaran terlebih dahulu, asalkan hasil karya cipta memenuhi syarat-syarat sebagai berikut:

- Karya tersebut asli hasil karya dari pemilik Hak

- Karya sudah diwujudkan dalam suatu bentuk yang termasuk ruang lingkup Hak Cipta

- Karya tersebut pertama kali dipublikasikan di Malaysia.

Ciptaan yang dilindungi di Malaysia meliputi :

- Karya sastra

- Karya Musik

- Karya Seni

- Film

- Rekaman suara

- Broadcast

- Karya berupa pengalihwujudan

Karya yang dapat perlindungan adalah karya yang sudah diwujudkan dalam suatu bentuk yang merupakan ruang lingkup Hak Cipta, jadi bukan merupakan ide.

Pemilik Hak Cipta di Malaysia adalah mereka yang menghasilkan karya tersebut. Jika suatu karya dihasilkan seorang pegawai sebagai suatu tugas dan tanggung jawab dalam pekerjaannya, maka pemilik Hak Cipta adalah pemberi pekerjaan. 
Jangka waktu perlindungan Hak cipta untuk karya tulis, karya musik, dan karya seni dilindungi seumur hidup pencipta dan dapat diperpanjang selama 50 tahun sejak meninggalnya pencipta. Jika pencipta ada 2 orang jangka waktu seumur hidup pencipta yang hidup terlama dan perpanjangan 50 tahun sejaka pencipta terakhir meninggal dunia.

Untuk karya cipta berupa rekaman suara, jangka waktunya 50 tahun sejak pertama kali dipublikasikan. Juga untuk karya berupa hak penyiaran dan film.

Untuk karya-karya yang termasuk budaya bangsa juga termasuk objek yang dilindungi dalam Act 332.

Untuk mengumpulkan royalti yang diperoleh dari karya-karya cipta, Malaysia memiliki Collective Malaysian Organization (CMO).

Selain itu Malaysia juga memiliki Asosiasi dibidang hak cipta, yaitu :

- Motion Picture Perizinan Malaysia

- MACP (Perlindungan Hak CiptaMusik Penulis)

- PRISM (Pelaku Hak dan Artistes Malaysia)

- PPM (Publik Kinerja Malaysia)

Pembentukan asosiasi-asosiasi dimaksudkan untuk membantu menegakkan perlindungan hak cipta sejalan dengan aturan yang ada dalam undang-undang.

Setelah peneliti mempelajari UUHC Indonesia dan Act 332, kedua negara memiliki perundangan hak cipta yang sama. Hal ini dikarenakan Indonesia dan Malaysia membuat undang-undang hak cipta berdasarkan aturanaturan mengenai hak cipta yang terdapat dalam konvensi-konvensi internasional, yaitu Berne Convention dan juga World Intellectual Property Organization (WIPO) dan TRIP's Agreement.

Pada ujung abad ke-20 dan awal abad ke-21 tercapai kesepakatan negaranegara untuk mengangkat konsep HKI ke arah kesepakatan bersama dalam wujud Agreement Establishing the World Trade Organization ("WTO Agreement") dan 
segala perjanjian internasional yang lampirannya, termasuk yang menyangkut HKI. $^{21}$

WTO Agreement ini diratifikasi oleh Indonesia dengan Undang-Undang No. 7 tahun 1994 tentang Pengesahan Persetujuan Pembentukan Organisasi Perdagangan Dunia ${ }^{22}$. Dengan demikian secara hukum Indonesia telah terikat dengan ketentuan-ketentuan tentang HaKI dalam GATT (General Agreement on Tariff and Trade atau Persetujuan Umum mengenai Tarif dan Perdagangan). Salah satu lampiran dari persetujuan GATT adalah Persetujuan tentang Aspekaspek Dagang Hak atas Kekayaan Intelektual (Agreement on Trade Related Aspects of Intellectual Property Rights) disingkat TRIPs, yang merupakan standar internasional yang harus disepakati berkaitan dengan HKI. HKI terdiri dari Hak Cipta dan hak-hak yang terkait, Merek Dagang, Indikasi Geografis, Desain Industri, Paten, Hak atas Topografi Rangkaian Terpadu Semikonduktor, Perlindungan mengenai Undisclosed Information, dan Pengawasan Terhadap Praktek yang Membatasi Konkurensi Dalam Kontrak Lisensi. ${ }^{23}$

Malaysia meratifikasi WTO Agreement pada tanggal 15 April 1994. Inilah yang menyebabkan aturan-aturan tentang hak cipta yang ada di kedua negara sama.

Mengenai adanya beberapa lagu, tari, dan kebudayaan Indonesia yang diakui Malaysia sebagai kebudayaan asli negaranya karena adanya Undangundang Warisan Nasional Malaysia (National Heritage Act) 2005.

Beberapa pasal dalam undang-undang ini, diantaranya pasal 69-70 yang menyebabkan adanya pengakuan terhadap budaya Indonesia. Berdasarkan Pasal 69, dengan judul kepemilikan (ownership), setiap warisan nasional yang dimiliki atau dikuasai oleh orang di luar Pemerintah Federal atau Pemerintah Negara Bagian, dapat tetap menguasai sebagai pemilik, wali atau orang yang dipercaya.

\footnotetext{
${ }^{21}$ Achmad Zen Umar Purba, Op. Cit., hal. 1.

${ }^{22}$ Diundangkan tanggal 2 November 1994 dan dimuat dalam Lembaran Negara Nomor 57 dan Tambahan Lembar Negara Nomor 3564

${ }^{23}$ Cita Citrawinda Priapantja, Op. Cit., hal. 2.
} 
Menjadi pertanyaan adalah, siapakah yang akan terdaftar sebagai pemilik dalam Lembaran Negara Malaysia berdasarkan pasal ini ${ }^{24}$

Pasal 70 yang berjudul Perubahan atas Kepemilikan Warisan Nasional. Disebutkan pada Pasal 70 ayat (2), pemilik warisan nasional bila hendak menjual kepada pihak ketiga maka pemilik harus memberi prioritas pertama kepada komisioner warisan nasional. Dalam hal ini yang mewakili pemerintah Malaysia.

Berdasarkan kedua pasal ini Malaysia dapat menguasai kebudayaan negara lain jika ada komunitas masyarakat adat yang sudah lama menetap di Malaysia dan sudah menjadi warga negara Malaysia mendaftarkan budayanya di Malaysia.

\subsection{Hak Cipta Indonesia dan Hak Cipta Malaysia dalam Sebuah Putusan}

Untuk menambah pemahaman mengenai aturan hak cipta di Indonesia dan malaysia,ada baiknya kita telaah kasus yang hampir sama.

Dalam sebuah putusan Mahkamah Agung Republik Indonesia No. 596 K/Pdt.Sus/2011 25 , dengan kasus terdapat kesamaan design kemasan makanan ikan antara tergugat dan penggugat. Kasus ini terjadi antara Thedy Gunardi Teguh merupakan Penggugat. Harli merupakan Tergugat. Penggugat adalah pemilik/ penanggungjawab perusahaan CV. ASIA PASIFIC QUATICS, berdasarkan Surat Izin Usaha Perdagangan (SIUP), Departemen Perdagangan Republik Indones ia Nomor 2212/P/1331/09- 04/PM/87 tertanggal 23 Juni 1987, untuk jenis kegiatan usaha ekspor, penyalur dan impor, berupa perdagangan hasil - hasil perikanan, makanan ikan dan udang yang bera lamat di Jalan Raya Lapangan Roos No. 34, RT. 002/06, Kelurahan Bukit Duri, Kecamatan Tebet, Jakarta Selatan. Bahwa Penggugat telah mendaftarkan perusahaan CV. Asia Pasific Aquatics tersebut pada Departemen Perdagangan Republik Indonesia dengan Nomor Pendaftaran 09033600164, tertanggal 30 November 1990. Penggugat telah melakukan

\footnotetext{
24 Hikmahanto Juwana, "UU Malaysia Ancam Budaya Indonesia", [www.hukumonline.com], diakses tanggal 19 Juni 2012.

${ }^{25}$ Putusan Mahakamah Agung Republik Indonesia No. 596/K/Pdt.Sus/2011, 28 September 2011.
} 
pendaftaran kembali izin tempat usaha, berdasarkan Undang-Undang Gangguan, Nomor 696/3 / JB/X/1994, pada Kantor Ketentraman dan Ketertiban DKI Jakarta, tertanggal 13 November 1994. Bahwa jen i s barang dagangan utama Penggugat adalah hasil - hasil perikanan, makanan ikan dan udang. Makanan ikan produksi Penggugat yang diperdagangkan oleh Penggugat mempergunakan kemasan makanan ikan dengan kata TUBIFEX WORMS, produksi "Astic - Pets" singkatan dari Asia Pasipic Aquatics (perusahaan milik Penggugat) yang disertai dengan gambar seni lukis DUA IKAN dalam 4 (empat) persegi dengan aneka hewan laut, yang dilukis dengan warna biru, merah, hijau dan abu- abu. Perdagangan makanan ikan dengan menggunakan kemasan dengan kata TUBIFEX WORMS, produksi "Astic - Pets" telah dilakukan sejak tahun 1995. Penggugat juga mendaftarkan Hak Cipta atas kemasan tersebut terdaftar di dalam Surat Pendaf taran Ciptaan Depar temen Hukum dan Hak Asasi Manusia Republik Indones ia Nomor 033488, ter t angga 106 Juni 2007

Ternyata, di pasaran perdagangan makanan ikan telah beredar makanan ikan dengan nama "Kiki - Pets" milik Tergugat, yang gambar kemasannya sangat mirip dengan gambar kemasan makanan ikan dengan kata TUBIFEX WORMS, produksi "Astic - Pets" singkatan dari Asia Pasific Aquatics (perusahaan milik Penggugat) yang bergambar seni lukis DUA IKAN dalam 4 (empat ) perseg i dengan aneka hewan laut, yang di lukis dengan warna biru, merah, hijau dan abuabu, dan yang telah lama diumumkan oleh Penggugat sebagai Pemilik melalu i perdagangan makanan ikan sejak tahun 1995. Tergugat ternyata telah mendaftarkan gambar kemasan tersebut pada tangga 19 November 2006 dan Departemen Hukum dan Hak Asasi Manusia Republik Indonesia telah menerbitkan Surat Pendaftaran Ciptaan, Departemen Hukum dan Hak Asasi Manusia Republi k Indonesia, Nomor 031961, tertanggal 18 Desember 2006 milik Tergugat. Penggugat menuntut pembatalan atas dikeluarkannya Surat Pendaftaran Ciptaan tersebut.

Dalam putusannya, hakim memutuskan sebagai berikut :

1. Mengabulkan gugatan Penggugat untuk seluruhnya ; 
2. Menetapkan Penggugat sebagai pencipta atau pemegang hak cipta atas gambar seni lukis dua ikan dalam empat persegi dengan aneka hewan laut yang menggunakan warna biru, merah, hijau dan abu- abu;

3. Menyatakan pendaftaran hak cipta yang telah dilakukan oleh Penggugat dengan No. Pendataran 033488, tanggal 10 Apr i 12007 adalah sah menurut hukum;

4. Menyatakan perbuatan Tergugat yang mendaftarkan gambar dua ikan dalam empat persegi dengan aneka hewan laut yang menggunakan warna biru , merah, hijau dan abu- abu yang terdaftar didalam Daftar Umum Ciptaan No. 031961, 9 November 2006 adalah perbuatan melawan hukum dan tidak beritikad baik ;

5. Menyatakan pendaftaran ciptaan a quo yang telah dilakukan oleh Tergugat dengan No. Pendaftaran 031961 tidak mempunyai kekuatan hukum;

6. Memerintahkan agar Turut Tergugat menghapus atau mencoret No. Pendaftaran 0311961 tersebut dar i Daftar Umum Ciptaan ;

7. Membebankan biaya perkara kepada Tergugat

Dari kasus ini dapat terlihat bahwa pendaftaran dalam Hak Cipta hanya untuk formalitas dan untuk memperoleh surat pendaftaran Hak Cipta, yang menjadi dasar siapa pemilik Hak Cipta adalah kapan ide diwujudkan dan siapa yang menggunakan dan mengumumkannya pertama kali.

Di Malaysia juga ada kasus yang serupa yaitu Lam Soon (M), Bhd v Forward Supreme sdn Bhd \& Ors. Dalam kasus ini terdapat design logo yang sangat mirip antara penggugat dan tergugat. Putusan yang dijatuhkan adalah penggugat dianggap tidak berhak menggunakan design logo tersebut karena yang terlebih dulu menggunakan adalah tergugat. Dan tergugat sudah lebih dulu menggunkan logo tersebut dalam perdagangan.

Dari kasus ini pun terlihat untuk Hak Cipta siapa yang mewujudkan dan menggunakan karya cipta itu terlebih dahulu maka dialah yang berhak sebagai pemegang Hak Ciptanya.

Dari 2 putusan atas kasus-kasus ini dapat kita lihat penerapan hukum Hak Cipta yang sama di kedua negara. Hal ini tidaklah mengherankan karena landasan aturan Hak Cipta di kedua negara berdasarkan pada WTO Agreement. 


\section{PENUTUP}

\section{KESIMPULAN}

Berdasarkan penelitian yang telah dilakukan, maka kesimpulan yang dapat dikemukakan:

1. Di kedua negara yaitu Indonesia dan Malaysia berlaku undang-undang Hak Cipta yang secara keseluruhan hampir sama. Hal ini dikarenakan Indonesia dan Malaysia meratifikasi konvensi-konvensi internasional yang sama. Yang diperlukan agar suatu karya dapat dilindungi berdasarkan Undang-undang Hak Cipta adalah diwujudkannya ide kedalam suatu bentuk yang termasuk dilindungi berdasarkan undang-undang. Dengan syarat karya yang dihasilkan asli dibuat oleh pencipta, karya tersebut ada dalam ruang lingkup ilmu pengetahuan, seni dan sastra, juga merupakan suatu karya yang baru, tidak menyerupai atau sama dengan karya-karya yang sudah pernah ada.

2. Pelaksaan perlindungan Hak Cipta berdasarkan undang-undang yang berlaku sudah dijalankan walaupun belum maksimal. Hal ini dikarenakan pemahaman tentang Hak Cipta di masyarakat masih rendah. Pembentukan Dewan Hak Cipta, Malaysian Collective Organization, asosiasi-asosiasi Hak Cipta di masing-masing negara, juga pembentukan Tim Nasional Penanggulangan Pelanggaran HKI, berdasarkan Keppres No. 4 tahun 2006 dan dibentuknya Direktorat Penyidikan di Direktorat Jenderal HKI oleh Departemen Hukum dan HAM pada tahun 2010, menunjukkan keseriusan pemerintah menegakkan undang-undang Hak Cipta.

\section{SARAN}

1. Hendaknya pemerintah Indonesia dan Malaysia melakukan sosialisasi dan peningkatan pemahaman yang lebih tinggi kepada seluruh kalangan masyarakat mengenai Hak Cipta dan cara-cara perlindungannya.

2. Sebaiknya pemerintah Indonesia yang memiliki beragam budaya bangsa yang merupakan aset negara harus dapat melakukan tindakan lebih nyata 
untuk melindungi budaya-budaya bangsa yang dilindungi dengan undangundang Hak Cipta.

\section{DAFTAR PUSTAKA}

Direktorat Jenderal Hak Kekayaan Intelektual. Buku Panduan Hak Kekayaan Intelektual. Jakarta: Departemen Kehakiman Hak Asasi Manusia Republik Indonesia, 2003.

Dodi Ft. "Sekilas tentang Hak Cipta". [www.kompasiana.com]. Diakses pada 19 Februari 2010

Juwana, Hikmahanto. "UU Malaysia Ancam Budaya Indonesia". [www.hukumonline.com]. Diakses pada 19 Juni 2012

Mahkamah Agung Republik Indonesia, Putusan No. 596/K/Pdt.Sus/2011, 28 September 2011

Priapantja, Cita Citrawinda. Budaya Hukum Indonesia Menghadapi Globalisasi Perlindungan Rahasia Dagang di bidang Farmasi. Jakarta: Chandra Pratama, 1999.

Purba, Achmad Zen Umar. Hak Kekayaan Intelektual Pasca TRIPs. Bandung: Alumni, 2005.

Purba, Afriliyani, dkk. TRIP's-WTO \& Hukum HKI Indonesia. Bandung: Rineka Cipta, 2005.

Riswandi, Budi Agus. Hak Kekayaan Intelektual dan Budaya Hukum. Jakarta: RajaGrafindo Persada, 2005.

Saidin, H. OK. Aspek Hukum Kekayaan Intelektual, Rajagrafindo Persada, Jakarta, 2006, hal 9-10

Soenandar, Taryana. Perlindungan Hak Milik Intelektual di Negara-Negara ASEAN. Jakarta: Sinar Grafika, 1996. 